\title{
PERTUMBUHAN DAN HASIL TIGA VARIETAS KEDELAI DI GAWANGAN DENGAN PEMOTONGAN UJUNG PELEPAH KELAPA SAWIT
}

\author{
GROWTH AND YIELD OF THREE VARIETIES OF SOYBEANS IN \\ INTER-ROW WITH CUTTING ON PALM OIL FRONDS TIP
}

\author{
Iqbal Effendy*, Novianto dan Dia Utami \\ Program Studi Agroteknologi Fakultas Pertanian Universitas Musi Rawas \\ Jalan Pembangunan Kompleks Perkantoran Pemkab Mura, Lubuklinggau \\ *Email: iqbaleffendy47@yahoo.com
}

\begin{abstract}
Oil palm plantations in Indonesia are the largest one in the world, reaching 12.3 million hectares, around $46 \%$ are smallholders with very low productivity couse income of oil palm farmers is very low. One effort to take over the problems is to develop an intercroping pattern of soybean-oilpalm by trimming the tips of the midribs of oil palm plants on thewider side of interspace of palm stand rows, to increase light interception accepted by soy bean plant surfaces. This study used a randomized block design (RBD) arranged in factorial $4 \times 3$ with three replications. The first treatment is cutting the edge of the oil palm midrib, namely $P 1=50 \mathrm{~cm}, P 2=100 \mathrm{~cm}, P 3=150 \mathrm{~cm}$. The second treatment was low light intensity tolerant soybean varieties, namely: V1 = Dena 1, V2 = Anjasmoro and V3 = Detam 1. Other actions were carried out according to generally accepted standards. To see the effect of treatment carried out the $F$ test at the level of 5\%, and continued with the HSD test at the level of 5\% to see the difference among treatments. The results showed that a hope of developing soybean plants as intercrops, although statistically did not show a significant difference. FFB results were not significantly affected by the act of trimming the midrib as $150 \mathrm{~cm}$.
\end{abstract}

Keywords: Intercropping, soybean, and oil palm

\begin{abstract}
ABSTRAK
Kebun kelapa sawit di Indonesia terluas di dunia, telah mencapai 12,3 juta ha, sekitar 46\% merupakan kebun rakyat (smallholder) dengan produktivitas sangat rendah sehingga pendapatan petani sawit juga sangat rendah. Salah satu upaya untuk mengatasi masalah ini adalah dengan mengembangkan pola intercropping sawit-kedelai dengan pemangkasan ujung pelepah tanaman kelapa sawit disisi gawangan lebar sehingga memungkinkan untuk budidaya tanaman kedelai sebagai tanaman sela.Penelitian ini meggunakan rancangan acak kelompok (RAK) yang disusun secara factorial $4 \times 3$ dengan tiga kali ulangan. Perlakuan pertama adalah: Perlakuan pemotongan ujung pelepah kelapa sawit, yaitu $\mathrm{P} 0=$ Diluar gawangan sebagai kontrol, $\mathrm{P} 1=50 \mathrm{~cm}, \mathrm{P} 2=100 \mathrm{~cm}$, dan P3= $150 \mathrm{~cm}$. Perlakuan kedua, varietas kedelai (toleran cahaya rendah) yaitu: V1 = Dena 1, V2 = Anjasmoro, dan V3 = Detam 1. Untuk melihat pengaruh perlakuan dilakukan uji $\mathrm{F}$ pada taraf 5\%, dan dilanjutkan dengan uji
\end{abstract}


BNJ pada taraf $5 \%$ untuk melihat perbedaan perlakuan. Hasil penelitian menunjukkan harapan pengembangan tanaman kedelai sebagai tanaman sela walaupun secara statistik belum menunjukkan perbedaan yang nyata. Hasil TBS tidak dipengaruhi oleh tindakan pemangkasan ujung pelepah hingga $150 \mathrm{~cm}$.

Kata Kunci : Kedelai, kelapa sawit, pelepah

\section{PENDAHULUAN}

Rendahnya produktivitas kebun sawit rakyat yang berakibat pada rendahnya pendapatan petani kebun sawit rakyat, memicu pencarian pola tanam yang dapat mendongkrak pendapatan petani sawit. Salah satu pola tanam yang dikembangkan dalam rangka meningkatkan atau memaksimalkan penggunaan sumber daya dan meningkatkan hasil dari lahan pertanian adalah melalui pola intercroping atau tumpang sari, yang merupakan tindakan menanam beberapa jenis (multiple croping) tanaman secara bersamaan (simultaneous) atau secara bergiliran (crop rotatian) pada sebidang tanah dalam jangka waktu tertentu (Tilman et al., 2002).

Selanjutnya dikemukakan olehEffendy (2016), lahan perkebunan seperti kebun kelapa sawit, kebun karet, kebun kelapa dan lain-lain dapat dimanfaatkan sebagai lahan pengembangan pola intercropping dengan tanaman pangan, sekaligus mendukung upaya pemerintah dalam meningkatkan produksi tanaman pangan (food crops) dan menjaga keamanan pangan nasional (national food security). Pola tanaman intercroping dapat memberikan keuntungan dari berbagai segi, seperti dapat meningkatkan hasil petani melalui peningkatan NKL (nilai kesetaran lahan) yang pada akhirnya meningkatkan pendapat petani. Keuntungan pola intercroping menurut Li et al.
(2011) yaitu dapat meningkatkan hasil, efisiensi sumber daya lingkungan yang berbeda, menekan hama dan penyakit serta dapat meningkatkan fiksasi nitrogen secara biologis. Dengan demikian intercroping cenderung mendorong terciptanya pertanian berkelanjutan yang ramah lingkungan.

Tanaman sawit menjadi komoditas perkebunan terpenting di Indonesia karena perannya sebagai penyumbang devisa negara, penyedia jutaan lapangan kerja dan mampu meningkatkan perekonomian di Indonesia (Corley and Tinker, 2016 dan Waruwu et al., 2018). Menurut Effendy et al. (2019), luas areal perkebunan kelapa sawit di Indonesia tahun 2017 mencapai 12,3 juta ha dan merupakan perkebunan kelapa sawit yang terluas di dunia, mampu memproduksi CPO pada tahun 2017 mencapai 35,3 juta ton dan menduduki posisi pertama eksportir CPO dan KOP di dunia (Ditjenbun 2017). Walaupun Ratarata produktivitas perkebunan rakyat kelapa sawit di Indonesia masih sangat rendah dibawah 5 ton Tandan Buah Segar(TBS) ha ${ }^{-1}$ tahun $^{-1}$, sementara potensi produksi bila memenuhi kretaria pengelolaan yang optimum mampu menghasilkan 20 - 30 ton TBS per ha per tahun(Herman dan Pranowo, 2011).

Potensi pengembangan intercroping dapat memanfaatkan lahan dengan tanaman pangan (food crops) terutama intercroping sawit-kedelai atau pajale 
sangat memungkinkan dikembangkan di Indonesia mengingat luasnya perkebunan sawit rakyat yang mencapai $45-46 \%$ dari total luas perkebunan sawit atau lebih kurang 5,5 juta hektar, memberikan peluang yang besar untuk dikembangkannya pola tanam intercroping sawit-pajale (padi jagung kedelai). Namun pengembangan pola tanam intercroping sawit kedelai secara teknis agronomis terkendala oleh beberapa faktor seperti rendahnya cahaya dibawah tegakan tanaman perkebunan atau gawangan sawit (Effendy, 2018). Belum banyak varietas pajale yang betul-betul toleran cahaya intensitas rendah yang telah diintroduksi dan dikenal masyarakat tani atau belum intensifnya penyuluhan tentang pemanfaatan lahan diantara tanaman perkebunan atau kehutanan menjadi sisi lain lambatnya pemanfaatan lahan perkebunan dan kehutanan ini dalam upaya pengembangan pola tanam intercroping.

Rendahnya intensitas cahaya yang diterima tanaman sela (intercroping) di bawah kanopi dalam sistem budidaya campuran menjadi penghambat produktivitas tanaman sela. Hasil penelitian Effendy et al. (2014) terhadap beberapa genotipe jagung yang toleran dan yang peka terhadap intensitas cahaya rendah menunjukkan terjadi perubahan performa karakter tanaman jagung yang ditanam dengan kondisi intensitas cahaya rendah seperti meningkatkan tinggi tanaman, luas total daun, luas daun spesifik dan kandungan klorofil daun, namun tetap menurunkan hasil biomas dan produksi biji pipilan dibandingkan dengan tanaman kontrol (intensitas cahaya penuh). Pada kondisi intensitas cahaya rendah, berakibat pada kurangnya energi penggabungan karbodioksida dan air dalam proses fotosintesis untuk menghasilkan fotosintat. Sementara Sopandie, et al (2003) mengatakan penurunan laju fotosintesis yang berakibat pada penurunan hasil hanya dapat diimbangi dengan meningkatkan efisiensi respirasi, sehingga hasil fotosintesis tidak habis terombak oleh proses respirasi.

Kedelai di Indonesia merupakan komoditas pangan strategis setelah padi dan jagung, sehingga menjadi komoditas target dalam swasembada pangan (Handriawan et al., 2016), rata-rata konsumsi kedelai mencapai 8,12 kg per kapita per tahun (Sudaryanto dan Swastika 2007), dari segi kandungan nutrisi, biji kedelai memiliki kandungan gizi yang terdiri dari $40 \%$ - $45 \%$ protein, $18 \%$ lemak, $24 \%$ - 36\% karbohidrat, 8\% kadar air, asam amino dan kandungan gizi lainya yang bermanfaat bagi manusia. Disamping itu, kedelai juga dapat digunakan sebagai bahan baku industri, pakan ternak dan juga untuk pembuatan minyak kedelai (Suprapto, 2002). Menurut Taufik dan Novo (2004) biji kedelai mengandung fofor, besi, kalsium, vitamin B serta asam tak jenuh yang dapat mencegah pengerasan pembuluh nadi.

Produksi kedelai perlu ditingkatkan karena hingga saat ini produksi nasional baru mampu memenuhi $35 " 40 \%$ dari kebutuhan dalam negeri dengan produksi 963,10 ton biji kering tahun 2015 (BPS, 2015). Ratarata pertumbuhan produksi kedelai 3,25\% per tahun, sementara kebutuhannya mencapai 2 juta ton per tahun, sehingga pemerintah harus melakukan impor. Produksi kedelai tahun 2015 sebayak 963,10 ribu ton biji kering, meningkat sebayak 8,10 ribu ton $(0,85 \%)$ 
dibandingkan tahun 2014. Peningkatan produksi tersebut terjadi di luar Jawa sebanyak 30,41 ribu ton, sementara di pulau Jawa sebagai sentra produksi terjadi penurunan produksi. Salah satu penyebabnya adalah menyempitannya lahan produktif sebanyak 22,31 ribu ton. Rendahnya produksi kedelai di Indonesia disebabkan oleh produktivitas yang rendah, di samping luas areal taman yang masih belum seseuai dengan kebutuhan, dengan produktivitas 1,55 ton pada tahun 2014 maka sedikitnya dibutuhkan luas lahan pertanaman kedelai sekitar 2 juta ha (Handriawan et al., 2016), untuk itu diperlukan upaya ekstensifikasi lebih kurang 1,4 juta ha untuk mencukupi kebutuhan. Oleh karena semakin sulitnya mendapatkan lahan yang sesuai, maka uapaya pengembangan intercroping kedelai dengan tanaman perkebunan atau kehutanan dapat menjadi alternatif solusi masalah ini (Sundari, 2016).

Tanaman kedelai termasuk tanaman C3 yang membutuhkan sinarmatahari penuh. Untuk memperoleh produksi kedelai yang optimal sebagai tanaman sela di areal perkebunan, dibutuhkan varietas yang relatiftahan atau toleran terhadap naungan (kondisi intensitas cahaya rendah). Cekaman naungan sebesar 50\% terhadap tanaman kedelai yang sangat toleran tidak mengakibatkan penurunan signifikan pada jumlah polong, ukuran biji tanaman (Soverda et al., 2009). Perlakuan dengan pemberian naungan pada kedelai akan mempengaruhi sifat morfologi tanaman. Morfologi tanaman yang dapat dipengaruhi oleh naungan adalah batang tidak kokoh karena garis tengah batang lebih kecil sehingga tanaman menjadi mudah rebah
(Adisarwanto, 2005). Menurut Zhang et al. (2011), respon tanaman pada suatu lingkungan tumpang sari dapat bersifat adaptif, sinergis atau antagonis sebagai akibat respon fisiologis tanaman terhadap perbedaan intensiats cahaya yang diterima. Hal ini tidak berlaku bagi tanaman yang toleran naungan yang cenderung lebih efisien dalam memanfaatkan cahaya. Pada batas naungan tertentu proses fisiologis tanaman berlangsung normal, tidak terjadi etiolasi dan kerebahan yang tertentunya tidak mempengaruhi hasil (Asadi et al., 1997).

Berdasarkan uraian di atas maka peneliti tertarik untuk melakukan penelitian pengaruh pemotongan ujung pelepah sawit terhadap pertumbuhan dan produksi tiga varietas tanaman kedelai tolerant cahaya rendah sebagai tanaman sela. Adapun tujuan penelitian ini untuk melihat pengaruh pemotongan ujung pelepah sawit terhadap intersepsi cahaya dalam meningkatkan pertumbuhan dan produksi kedelai melalui pola penanaman polikultur. Dengan penelitian ini diharapkan dapat menjadi pertimbangan dalam memenuhi tuntutan ekstensifikasi kedelai, mengingat semakin sulitnya mendapatkan lahan produktif yang menerapkan pola tanam monokultur.

\section{BAHAN DAN METODE}

Penelitian dilaksanakan di Desa Sukorejo sawit milik rakyat Desa Sukorejo $\left(3^{0} 8.4760\right.$ 'S dan $102^{\circ}$ 54.8590'E), Kecamatan STLUlu Terawas Kabupaten Musi Rawas dengan ketinggian 92,5meter dpl, berlangsung selama 4 bulan dimulai pada bulan Februari 2019 hingga Mei 2019. Bahan-bahan yang 
digunakan dalam penelitian ini meliputi benih kedelai Varietas Dena 1, Anjasmoro dan Detam 1; pupuk Urea, SP-36, $\mathrm{KCl}$ dan inokulan legin. Alat yang digunakan dalam penelitian ini adalah timbangan analitis, alat pengukur intensitas cahaya,pH meter, termometer udara dan alat pengukur kelembaban udara dan alat panen sawit.

Penelitian ini menggunakan rancangan acak kelompok (RAK) yang disusun secara faktorial $4 \times 3$ dengan tiga kali ulangan.Perlakuan pertama adalah pemotongan ujung pelepah sawit kearah gawangan lebar, yaitu $\mathrm{P} 1=50 \mathrm{~cm}, \mathrm{P} 2=100 \mathrm{~cm}$ dan $\mathrm{P} 3=150$ cm. Perlakuan kedua varietas kedelai, yaitu : V1 = Varietas Dena 1,V2 = Varietas Anjasmoro, V3 = Varietas Detam 1. Masing-masing varietas ditanam di luar gawangan sebagai pembanding. Jarak tanam 40 $\mathrm{cm} \times 15 \mathrm{~cm}$, dua biji per lubang. Pemupukan dilakukan pada saat tanam dengan dosis pupuk Urea $50 \mathrm{~kg}$, SP36 $100 \mathrm{~kg}$ dan KCl $75 \mathrm{~kg} / \mathrm{ha}$. Sebelum tanam, benih diperlakukan dengan legin 7,5 g per $1 \mathrm{~kg}$. Perlakuan lain dilakukan sesuai dengan perlakuan yang berlaku umum.

Pengamatan penunjang dilakukan terhadap perubahan unsur iklim mikro seperti intersepsi cahaya, suhu dan kelembaban serta karakter agronomis tanaman kelapa sawit yaitu jumlah TBS, berat TBS dan total berat TBS, sedangkan untuk tanaman kedelai pengamatan dilakukan terhadaptinggi tanaman, jumlah polong, berat biji pertanaman dan berat berangkasan kering. Data yang diperoleh dianalisis secara manual untuk melihat pengaruh dari masing-masing sumber keragaman. Apabila terdapat pengaruh yang nyata terhadap perlakuan tunggal dan atau interaksinya, dilanjutkan dengan Uji BNJ untuk melihat pengaruh perlakuan yang terbaik pada taraf kepercayaan 5\% (Paiman, 2013).

\section{HASIL DAN PEMBAHASAN}

Pengamatan penunjang berupa intersepsi cahaya di bawah tajuk sawit memberikan pengaruh yang nyata akibat perlakuan pemotongan ujung sawit di gawangan lebar, hasil uji lanjut BNJ pada taraf $5 \%$, menunjukkan perbedaan yang nyata antara perlakuan pemotongan $50 \mathrm{~cm}, 100 \mathrm{~cm}$ dan $150 \mathrm{~cm}$. Sementara pengamatan terhadap suhu udara dan kelembaban udara (secara tabulasi) tidak menujukkan selisih yang besar antara ketiga perlakuan. Demikian juga terhadap peubah produksi sawit tidak terlihat pengaruh yang nyata. Bahkan terdapat kecenderungan peningkatan produksi sawit pada pemotongan ujung pelepah 150 cm (Tabel 1). Hasil penelitian menunjukkan bahwa perlakuan pemotongan ujung pelepah sawit memberikan pengaruh terhadap peubah dari ketiga varietas kedalai yang diuji. Secara statiktika pengaruh nyata terlihat pada penanaman di gawangan sawit dan di luar gawangan (tanaman kontrol)

Hasil uji lanjut BNJ terhadap peubah agronomis tanaman kedelai memperlihatkan bahwa tanaman kontrol dari ketiga varietas memberikan hasil yang lebih tinggi di banding yang ditanam di gawangan sawit, meskipun tanaman kedelai yang ditanam diklaim sebagai varietas toleran cahaya intensitas rendah (Tabel 2). Belum terlihat pengaruh pemotongan ujung pelepah terhadap semua peubah yang diamati. Hasil analisis 
Tabel 1. Pengaruh pemotongan ujung pelepah terhadap rerata Intersepsi cahaya, suhu, kelembaban,jumlah TBS, berat TBS dan berat total TBS (6 kali pengamatan)

\begin{tabular}{lcccccc}
\hline $\begin{array}{c}\text { Pemotongan ujung } \\
\text { pelepah }\end{array}$ & $\begin{array}{c}\text { Intersepsi cahaya } \\
\text { (LUX) }\end{array}$ & Suhu $\left({ }^{\mathbf{0}} \mathrm{C}\right)$ & $\begin{array}{c}\text { Kelembaban } \\
\text { udara }(\%)\end{array}$ & Jumlah TBS & $\begin{array}{c}\text { Rerata berat } \\
\text { TBS }(\mathrm{kg})\end{array}$ & $\begin{array}{c}\text { Total berat } \\
\text { TBS }(\mathrm{kg})\end{array}$ \\
\hline P1 $(50 \mathrm{~cm})$ & $7661,0 \mathrm{a}$ & 33,3 & 64,1 & 16 & 16,43 & 260,8 \\
P2 $(100 \mathrm{~cm})$ & $14126,33 \mathrm{~b}$ & 33,5 & 61,6 & 20 & 16,55 & 331 \\
P3 $(150 \mathrm{~cm})$ & $17563,33 \mathrm{~b}$ & 35,6 & 60 & 20,5 & 16,7 & 337,34 \\
\hline
\end{tabular}

Keterangan : Angka yang diikuti huruf yang sama pada kolom yang sama berarti tidak berbeda nyata pada taraf uji BNJ $5 \%$

Tabel 2. Pengaruh pemotongan ujung pelepah terhadap tinggi tanaman,jumlah polong, berat biji per tanaman dan berat berangkasan kering tiga varieta kedelai

\begin{tabular}{|c|c|c|c|c|}
\hline Perlakuan & Tinggi tanaman $(\mathrm{cm})$ & Jumlah polong (polong) & Berat biji (g) & $\begin{array}{c}\text { Berat berangkasan } \\
\text { kering }(\mathrm{g})\end{array}$ \\
\hline \multicolumn{5}{|l|}{ Pemotongan } \\
\hline \multicolumn{5}{|l|}{ ujung pelepah } \\
\hline $\mathrm{K}$ & 56,96 a & $23,89 \quad b$ & $15,83 \quad b$ & $15,83 \quad b$ \\
\hline $\mathrm{P} 1$ & $67,89 \quad b$ & 18,94 a & $9,84 \quad \mathrm{a}$ & $7,89 \quad \mathrm{a}$ \\
\hline $\mathrm{P} 2$ & $65,13 \mathrm{~b}$ & $20,97 \quad a$ & $10,00 \quad \mathrm{a}$ & 7,72 a \\
\hline P3 & $68,47 \quad b$ & $18,27 \mathrm{a}$ & $10,55 \quad \mathrm{a}$ & $7,61 \quad \mathrm{a}$ \\
\hline \multicolumn{5}{|l|}{ Varietas } \\
\hline $\mathrm{V} 1$ & 62,98 & 18,09 & 12,21 & 9,38 \\
\hline $\mathrm{V} 2$ & 64,60 & 20,29 & 11,22 & 9,79 \\
\hline $\mathrm{V} 3$ & 67,00 & 17,98 & 11,25 & 10,12 \\
\hline Interaksi & $(-)$ & $(-)$ & $(-)$ & $(-)$ \\
\hline BNJ P $(5 \%)$ & 3,54 & 3,66 & 2,27 & 2,08 \\
\hline
\end{tabular}

Keterangan : Angka rerata yang diikuti huruf yang sama pada kolom yang sama menunjukkan tidak berbeda nyata pada taraf uji BNJ $5 \%$, (-) menunjukkan tidak ada interaksi perlakuan.

varian perlakuan varietas menunjukkan tidak terdapat pengaruh yang signifikan untuk semua peubah yang diamati. Demikian juga tidak terdapat interaksi antara kedua perlakuan.

Tindakan pemotongan ujung pelepah sawit ditujukan untuk meningkatkan intersepsi cahaya matahari kebawah tajuk sawit. Sehingga di harapkan tanaman kedelai dapat menerima intensitas cahaya lebih besar. Perbedaan intensitas cahaya terlihat pada perlakuan pemotongan $(50 \mathrm{~cm}, 100 \mathrm{~cm}$ dan $150 \mathrm{~cm})$.
Intensitas cahaya pada pemotongan $50 \mathrm{~cm}$ adalah 7661 lux, pemotongan $100 \mathrm{~cm} \mathrm{14126,33} \mathrm{lux} \mathrm{dan}$ pemotongan $150 \mathrm{~cm} \mathrm{17563,33} \mathrm{lux.} \mathrm{Menurut}$ Handriawan et al. (2016), hal ini berimplikasi terjadinya penurunan jumlah pasokan fotosintat ke organ generatif tanaman kedelai sehingga akan menurunkan hasil produksi. Hasil pertumbuhan dan produksi berbagai kultivar menurun seiring dengan peningkatan intensitas naungan. Penurunan hasil produksi pada berbagai kultivar akibat naungan 
disebabkan oleh terhambatnya proses metabolisme tanaman akibat intensitas cahaya rendah. Hal ini mengakibatkan terjadinya penurunan jumlah pasokan fotosintat ke bagian biji.

Pada tinggi tanaman kedelai terdapat perbedaan yang nyata antara pemotongan pelepah pada pemotongan $50 \mathrm{~cm}, 100 \mathrm{~cm}$ dan $150 \mathrm{~cm}$ terhadap kontrol (Tabel 2), tetapi antara pemotongan pelepah sawit $50 \mathrm{~cm}, 100 \mathrm{~cm}$ dan $150 \mathrm{~cm}$ tidak terdapat perbedaan yang nyata. Penambahan tinggi tanaman ini diduga disebabkan perubahan status auxin dalam tanaman akibat perubahan ratio sinar merah dan sinar merah jauh yang dipicu oleh perubahan intensitas cahaya. Hal ini sejalan dengan Effendy et al., (2014) dan Handriawan et al., (2016), kondisi ini akan mengakibatkan tanaman akan meningkatkan pertumbuhan pada bagian tajuk (jaringan apikalis) untuk mendapatkan cahaya yang lebih besar, sebagai respon tanaman pada kondisi stres cahaya (mengalami etiolasi). Menurut Widiastuti et al. (2004),intensitas cahaya tinggi berpengaruh terhadap aktivitas auksin pada meristem apikal. Apabila intensitas cahaya tinggi maka aktivitas auksin meningkat pula, sehingga mengakibatkan tanaman tumbuh tinggi. Fungsi auksin pada pucuk tanaman untuk menghambat pertumbuhan tunas-tunas samping (cabang), dengan demikian meningkatnya kadar daminosida pada tanaman dapat memacu pemunculan cabang pada tanaman.

Penuruan intensitas cahaya berakibat pada kurangnya energi fotosintesis untuk menghasilkan fotosintat. Gejala ini ditunjukkan oleh ketiga varietas yang dicobakan. Ketiga peubah ini menunjukkan hasil yang lebih rendah dibandingkan dengan tanaman kontrol. Hal ini tentu saja berkaitan dengan optimalisasi kondisi lingkungan yang berada dibawah tajuk sawit dengan intensitas cahaya yang rendah, akan menghambat proses metabolisma secara keseluruhan yang berakibat pada rendahnya produksi polong, biji pertanaman dan berat berangkasan. Kondisi seperti ini juga dilaporkan peneliti lain seperti Anggraeni (2010), yang melaporan hasil penelitiannya bahwa tanaman yang ternaungi akan memiliki jumlah daun yang lebih sedikit dibandingkan tanaman yang mendapatkan cahaya penuh. Menurut Wirnas (2005) tanaman yang menerima intensitas cahaya rendah (ternaungi) mengakibatkan batang tanaman cenderung kecil dibanding kondisi intensitas cahaya penuh, disebabkan oleh xilem kurang berkembang karena pembesaran sel-sel pada batang terhambat. Susanto dan Sundari (2010), tanaman yang kekurangan intensitas cahaya mengakibatkan jumlah daun per tanaman berkurang, berkurangnya jumlah daun yang terbentuk berhubungan erat dengan pengurangan luas total daun.

Perlakuan pemotongan ujung pelepah tanaman sawit memberikan hasil tidak berbeda pada taraf 50 $\mathrm{cm}, 100 \mathrm{~cm}$ dan $150 \mathrm{~cm}$. Pemotongan ujung pelepah ini akan berdampak pada pengurangan luas daun total tanaman sawit, dengan pengurangan luas total ini akan dicapai indek luas daun optimal. Dari hasil pengamatan produksi TBS terdapat kecenderungan pemotongan yang lebih besar memberikan hasil berat TBS ratarata, jumlah TBS rata-rata dan berat total TBS pada akhir penelitian menunjukan angka yang lebih besar, 
hal ni diduga pengurangan luas daun total akibat pemotongan ujung pelepah diduga dapat mendekati angka LAI optimal, dimana pada kondisi LAI optimal ini akan dapat menghasilkan fotosintat yang maksimal, bila kondisi lapngan lainnya juga berada pada kondisi maksimal. Hasil fotosintat ini akan tercermin pada ratarata berat TBS yang dihasilkan. Disamping itu naiknya berat rata-rata TBS diduga sebagai akibat dari berkurangnya bagian tajuk tanaman yang bersifat parasit terhadap hasil fotosintesa. Diduga bagian ujung pelepah yang sudah melengkung ke bawah sama sekali tidak efektif dalam menerima cahaya matahari. Menurut Hermansyah, et.al. (2009), fotosintesis menghasilkan fotosintat yang bermanfaat bagi pertumbuhan vegetatif maupun generatif. Dengan aktifnya proses fotosintesis maka intensitas cahaya yang diterima juga akan menambah luas daun.

\section{KESIMPULAN}

Kesimpulan yang didapat dari penelitian ini adalah: 1) Pemotongan ujung pelepah sawit tidak berpengaruh terhadap semua peubah yang diamati pada tanaman kelapa sawit, walaupun hasil pemangkasan $150 \mathrm{~cm}$ cenderung lebih baik; 2) Varietas Kedelai Detam 1, varietas Denah 1 dan Anjasmoro tidak berpengaruh nyata terhadap semua peubah yang diamati; 3) Tidak terdapat interaksi antara pemotongan ujung pelepah sawit dan varietas kedelai.

\section{UCAPAN TERIMA KASIH}

Pada kesempatan ini penulis mengucapkan terimakasih pada Sdr. Romzi sebagai pemilik kebun sawit rakyat, yang telah mengizinkan dan memfasilitasi penelitian ini, sehingga dapat berjalan dengan lancar sesuai jadwal pelaksanaan penelitian.

\section{DAFTAR PUSTAKA}

Adisarwanto, T. 2005. Kedelai, Budaya dan Pemupukan yang Efektif dan Pengoptimalan bintil akar. Penebar swadaya. Jakarta.

Anggraeni, B.W. 2010. Studi morfo-anatomi dan pertumbuhan kedelai (Glycine max (1) Merr.) pada kultivar cekaman intensitas cahaya rendah. Skripsi Fakultas Pertanian IPB. Bogor

Asadi, B., D.M. Arsyad, H. Zahara, Darmijati. 1997. Pemuliaan kedelai untuk toleran naungan. Buletin Agrobio 1:15-20.

Badan Pusat Statistik (BPS). 2015. Produksi Kedelai Menurut Provinsi (ton) pada tahun 19932015. Jakarta (ID).

Corley, R,H,V and P.B Tinker. 2016. The Oil Palm. Fifth Edition.Wiley Blackwell, UK. 639 pp

Ditjenbun Direktorat Jendral Perkebunan. 2017. Lintasan 30 tahun tahun pengembangan kelapa sawit.http://ditjenbun.deptan.go.id/tanhun/ berita-176-lintasan-30-tahun-pengembangankelapa-sawit.html.diunduh pada tanggal 27 September 2017..

Effendy, I, U. Harun, D. Budianta dan Munandar.2014. Performa Karakter Daun Tanaman Jagung (Zea mays L) Ternaungi di Lahan Rawa Pasang surut. Jurnal Agronomika. 3 (1):22-33.

Effendy, I. 2016. Produksi beberapa genotipe jagung (Zea mays L) sebagai tanaman sela pada kebun 
kelapa sawit tanaman menghasilkan. Prospek Agroteknologi 5(2):17-24.

Effendy, I. 2018. Uji Adaptasi Pertumbuhan Vegetatif beberapa Genotipe Tanaman Jagung (Zea mays L) pada Berbagai Kondisi Ternaungi. Jurnal Prospek Agroteknologi. 7 (1): 38-48.

Effendy, I., Gribaldi dan Benny, A.J. 2019. Aplikasi sabut kelapa dan pupuk bokasi kotoran ayam terhadap pertumbuhan bibit sawit di pre nursery. Jurnal Agrotek Tropika. 7 (2):405-412

Handriawan, A., D. W. Respatie dan Tohari. 2016. Pengaruh Intensitas Naungan terhadap Pertumbuhan dan Hasil Tiga Kultivar Kedelai (Glycine max L.) Merill) di lahan Pasir Pantai Bugel, Kulon Progo. Vegetalika. 5 (30): 1-14.

Hermansyah, Sasmita.Y, Inoriah, E. 2009. Penggunaan Pupuk Daun dan Manipulasi Jumlah Cabang yang Ditinggalkan pada Panen Kedua Tanaman Nilam. Fakultas Pertanian Universitas Bengkulu. Akta Agrosia. 12.(2): 194-203.

Herman. M dan Pranowo. D. 2011. "Ciri Buah dan Minyak Kemiri Minyak (Reutealis trisperma (Blanco) Airy Shaw) Populasi Majalengka dan Garut”.Buletin Ristri 2(1): 21-27.

Li, Q.-Z., Sun, J.-H., Wei, X.-J., Christie, P., Zhang, F.-S., Li, L., 2011. Overyielding and interspecific interactions mediated by nitrogen fertilization in strip intercropping ofmaize with faba bean, wheat and barley. Plant and Soil. 339, 147-161.

Paiman. 2013.Perancangan Percobaan untuk Pertanian . UPY Press. Yogyakarta. 196 hal.
Soverda, N., Evita dan Gustiwati. 2009. Evaluasi dan Seleksi Varietas Tanaman Kedelai terhadap Naungan dan Intensitas Cahaya Rendah.

Soepandie, D., Chozin, M.A. Sastrosumarjo, S. Juhaeti, T. Dan Sahardi. 2003. Toleransi padi Gogo terhadap naungan. Hayati. 20 (2) : 71 75

Sudaryanto, T. dan D.K.S. Swastika. 2007. Ekonomi kedelai di Indonesia. Dalam Kedelai: Teknik Produksi dan Pengembangan. Pusat Penelitian dan Pengembangan Tanaman Pangan, Bogor.

Sundari, Titiek. 2016. Penampilan galur-galur kedelai toleran naungan di dua lingkungan. Performance of shade tolerance soybean lines in two environmen. Bulletin Palawija. 14(2):63-70.

Suprapto, H. 2002. Bertanam Kedelai. Penebar Swadaya. Jakarta. 74 hal.

Susanto, G.W.A dan Sundari. T., 2010. Pengujian 15 Genotipe Kedelai pada kondisi Intensitas Cahaya 50\% dan Penilaian Karakter Tanaman Berdasarkan Fenotipnya. Balai Penelitian Kacang-kacangan dan Umbi-Umbian, Malang. Jurnal Biologi Indonesia 6 (3): 459471.

Tilman, D., Cassman, K.G., Matson, P.A., Naylor, R., Polasky, S. 2002. Agricultural sustainability and intensive production practices. Nature. 418, 671-677

Taufiq, T.M.M. dan I. Novo. 2004. Kedelai, Kacang Hijau dan Kacang Panjang. Absolut Press. Yogyakarta 
Widiastuti.L, Tohari dan Sulistyaningsih. E. 2004. Pengaruh Intensitas Cahaya dan Kadar Daminosida Terhadap Iklim Mikro dan Pertumbuhan Tanaman Krisan dala Pot. Ilmu Pertanian. 11(2) : Hal 35-42

Wirnas, D. 2005. Analisa kuantitatif dan molekuler dalam rangka mempercepat perakitan varietas baru kedelai toleran terhadap intensitas cahaya rendah. http:// www.tomotou. Net/ pps702_9145/desta_wirnapdf.
Waruwu, F., Simunihuruk, B.W., Prasetyo dan Hermansyah. 2018. Pertumbuhan bibit kelapa sawit di pre-nursery dengan komposisi media tanam dan konsentrasi pupuk cair Azolla pinnata berbeda.JIPI 20 (1):7-12.

Zhang J, Smith DL, Liu W, Chen X, Yang W. 2011. Effects of shade and drought stress on soybean Hormones and yield of main-stem and branch. The African Jurnal of Biotech. 10(85):14392-14398. 